\title{
Increasing carbon sinks through forest management: a model-based comparison for Switzerland with its Eastern Plateau and Eastern Alps
}

\author{
Esther Thürig • Edgar Kaufmann
}

Received: 1 April 2009/Revised: 2 December 2009/Accepted: 23 December 2009/Published online: 3 February 2010

(C) Springer-Verlag 2010

\begin{abstract}
The Kyoto Protocol brought a new forest function into focus: forests as carbon sinks. This new forest function may lead to new conflicts, because on the one hand, Switzerland has decided to account for forest management under Kyoto Protocol (Article 3.4), and on the other hand, Swiss Forestry statistics and the Swiss National Forest Inventory indicate that increasing amounts of wood are being harvested. This trend seems likely to continue. In this study, we used the empirical forest model MASSIMO and the soil model YASSO to analyse four different forest management scenarios. These scenarios basically feature different levels of harvesting frequencies and different rotation length, as well as their impact on regional potentials for carbon sequestration and harvesting amounts. Results were analysed both for the whole of Switzerland and for two very different regions: The Swiss Eastern Plateau and the Swiss Eastern Alps. The results indicate that Swiss forests can provide an increasing amount of harvested wood $(+18 \%$ in relation to the base year 1996) for approximately 20 years and act as a carbon sink accountable under the Kyoto Protocol (0.5 million tons carbon per year). The corresponding forest management strategy aims for a sustainable and harvestable increment and may, therefore, avoid spurious carbon maximization in forests that can happen by accounting for only forest systems, and not for the effect of substitution of non-wood products and fossil fuels by forest products. The regional results indicate that (1) the carbon sink effect of Alpine
\end{abstract}

Communicated by R. Matyssek.

E. Thürig $(\bowtie) \cdot$ E. Kaufmann

Swiss Federal Institute for Forest, Snow and Landscape

Research, Zürcherstrasse 111, 8903 Birmensdorf, Switzerland

e-mail: esther.thuerig@wsl.ch forests in Switzerland might be limited, because generally, Alpine forests have low growth and yield and (2) a large increase in harvesting may lead to regional carbon sources and necessitate regional monitoring of increment to avoid overexploitation. As MASSIMO does not include the impacts of climate change, the conclusions of this study cannot be interpreted as actual predictions into the future but portray the impact of the applied management actions on the respective trends in carbon stocks and stock changes. They are, therefore, a contribution to support future management decisions. Further studies should focus on interactions with additional forest functions such as the preservation of biodiversity, increase the consideration of forest damage and account for the effect of climate change.

Keywords Kyoto Protocol - Carbon sequestration . Forest modelling $\cdot$ Switzerland

\section{Introduction}

Beside traditional forest functions such as providing timber, protection and recreation, the Kyoto Protocol introduced the new forest function of carbon (C) sequestration (UNFCCC 1997). During recent decades, the increment has exceeded losses through cut $\&$ mortality in forests in the northern hemisphere, resulting in a $\mathrm{C}$ sink in those forests (Goodale et al. 2002). This is because of the particular age structure of the forest due to past exploitation (Birdsey et al. 2006; Liski et al. 2006; Ciais et al. 2008), the abandonment of agricultural land (Pacala et al. 2001) and a greater increment due to increases in temperature, atmospheric carbon dioxide and nitrogen (De Vries et al. 2006; Magnani et al. 2007; Zaehle et al. 2007). However, the most direct human influence on the $\mathrm{C}$ balance of forests is 
through forest management (De Vries et al. 2006; Ciais et al. 2008).

Irrespective of agreements of other nations, the European Union has made a commitment to reduce greenhouse gas emissions by $20 \%$ in 2020 compared to the level of 1990. Given the growing demand for energy and increasing energy prices, it has adopted an energy policy with a binding target to increase the share of renewable energies to $20 \%$ by $2020 .{ }^{1}$ Although Switzerland has not yet made any final commitment to reduction goals after 2012, it is also boosting renewable energy sources by providing remuneration for the costs of feeding renewable energy into the electricity grid. ${ }^{2}$ By substituting energy-intensively produced fossil materials and fuels, biomass plays an important role in reducing climate impacts (Gustavsson and Sathre 2006). This aspect of the use of wood may be in conflict with managing forests as carbon sinks.

To investigate this potential conflict and to find a compromise between carbon sequestration in forests and the substitution effect of wood, model simulations of different forest management scenarios are a common approach. The effects of different rotation lengths and thinning intensities have already been investigated in many studies (Schlamadinger and Marland 1996; Eriksson and Berg 2007; Eggers et al. 2008; Hennigar et al. 2008). However, most of these studies are either case studies of specific forest areas that are not representative for a country (Eriksson and Berg 2007), or the results have been aggregated across countries, concealing regional differences (Karjalainen et al. 2003).

Different spatial resolutions may lead to different assessments of the effects of forest management on $\mathrm{C}$ sequestration (Harmon 2001). Forests in Switzerland are spatially very heterogeneous with, for example, widely varying stand and age structure, growing stock, productivity, harvesting costs and priority ranking of forest functions. Those are, however, very important factors for determining the effectiveness in terms of $\mathrm{C}$ sequestration of different forest management strategies (Schlamadinger and Marland 1996), which means that the regional C sequestration effects of forest management scenarios can be very different from national effects. Therefore, it is best to examine the effectiveness of a scenario at different spatial resolutions.

This study aims to assess the impact of different forest management scenarios on the $\mathrm{C}$ sequestration potential and limits of forests. Using the models MASSIMO (Kaufmann 2000a, 2000b) and YASSO (Liski et al. 2005), four different management scenarios were run. As the effect of

\footnotetext{
${ }^{1} \mathrm{http} / / / \mathrm{ec}$. europa.eu/environment/climat/climate_action.htm (28.08.2009).

2 http://www.admin.ch/ch/d/as/2008/1223.pdf (28.08.2009).
}

climate change on forest ecosystems becomes even more important in the future (Watson et al. 2000), the informative value of model simulations based on constant environmental conditions becomes less over time (Thürig et al. 2005b). However, to demonstrate the impact of the possible management actions on the respective carbon stocks and stock changes of approximately one rotation period, simulations were run for the next 90 years (including 3 years already passed).. To analyse the effect of spatial scales, the results are shown as average values for Switzerland and for the regions Swiss Eastern Plateau and Swiss Eastern Alps. The results of the model simulations are shown for the periods 2008-2012, 2007-2026, 2007 2056 and 2057-2096 and discussed in terms of C stock changes in forests, amounts of cut \& mortality, increment and spatial differentiation of the results.

\section{Study area, models and scenarios}

\section{Study area}

In Switzerland, forests cover about $30 \%$ or $12340 \mathrm{~km}^{2}$ of the area (Brassel and Brändli 1999). Norway spruce (Picea abies, 40\%), beech (Fagus silvatica, 18\%) and silver fir (Abies alba, $11 \%)$ are the dominant tree species. As forest areas extend from 200 to $2200 \mathrm{~m}$ above sea level, they exhibit a large spatial heterogeneity in elevation, geology, soils, main tree species, stocking density of the forests, management regime and climate. Model simulations were done both for the whole of Switzerland and for the two regions Swiss Eastern Plateau (108 000 ha forest area) and Swiss Eastern Alps (124 000 ha forest area) (Fig. 1). In 1996, these two regions were comparable in the forest area but differed largely in the actual growing stock (422 and $304 \mathrm{~m}^{3} \mathrm{ha}^{-1}$ ), increment (13.4 and $6.0 \mathrm{~m}^{3} \mathrm{ha}^{-1}$ year $^{-1}$ ) and the level of cut \& mortality (11.9 and $4.6 \mathrm{~m}^{3} \mathrm{ha}^{-1}$ year $^{-1}$ ) (Brassel and Brändli 1999). All simulated values refer to the constant Swiss forest area of 1.065 million hectares representing the common forest area measured in the first (1983-1985) and the second (1993-1995) Swiss National Forest Inventory (NFI). Changes in the forest area were not considered.

\section{Management scenario simulation model MASSIMO}

The management scenario simulation model (MASSIMO) (Kaufmann 2000a; Kaufmann 2000b) is an empirical, individual-based, stochastic and dynamic forest model. It consists of four sub-models: regeneration, growth, mortality, and management scenarios (including harvesting). These four sub-models are empirical formulations derived from data from the first and the second Swiss NFI, based on 4400 sample plots (Brassel and Brändli 1999). Since the 


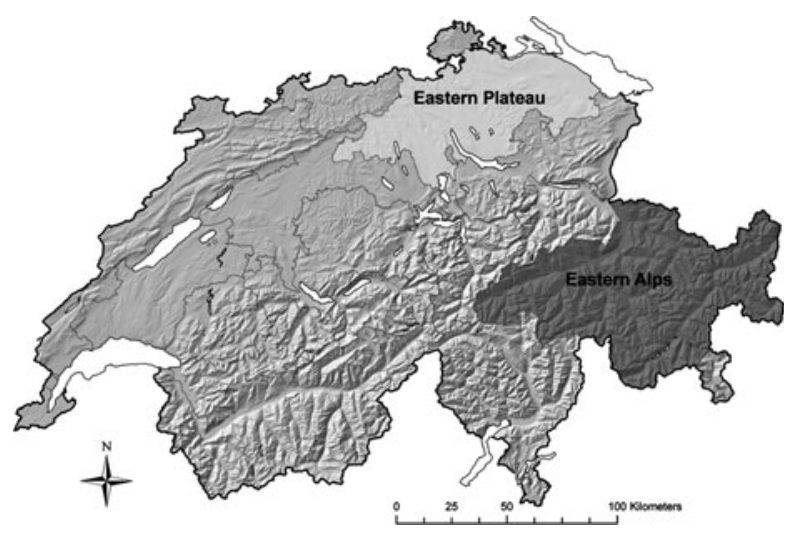

Fig. 1 Map of Switzerland, the Eastern Plateau and the Eastern Alps overlaid with the hill-shaded DTM25 $\left({ }^{\odot} 2004\right.$ Swisstopo). Lakes are shown in white for better spatial orientation

empirical formulations in MASSIMO are derived from NFI data, they are based on environmental conditions of the 1980s and early 1990s, and no climate change can be considered in the model. MASSIMO has already been used to assess various scenarios of Swiss forest development (Kaufmann 2000b; Schmid et al. 2006).

The empirical growth function constitutes the core of MASSIMO. It was derived from the Swiss inventory data and describes the decadal basal area increment (Kaufmann 2000b). The increment was estimated on an individual tree basis as a function of site conditions and forest structures. These are updated after each projection decade to take into account their influence on growth in the subsequent decade. It was validated with independent data by Thürig et al. (2005a).

Mortality was modelled as in Schmid et al. (2006), where density-dependent mortality was assessed according to findings from the long-term forest yield research plots of the Swiss Federal Research Institute (WSL), data from selected NFI plots with a high growing stock and expert knowledge. These data were used to empirically define the upper limit of stand densities in terms of stand basal area. The following relations were derived: when a simulated stand reaches the maximum basal area $\left(50-75 \mathrm{~m}^{2} \mathrm{ha}^{-1}\right.$, estimated depending on species composition and development stage), the mortality rate increases exponentially with increasing basal area. Mortality also increases exponentially in very old stands (older than 150 years in the Plateau, older than 250 years in the Alps).

Regeneration is also based on empirical data. NFI sample plots with young forests are stratified according to elevation and production region (i.e. Jura, Plateau, PreAlps, Alps and Southern Alps). After a total clear-cut, the eliminated stand is replaced by a randomly selected young forest sample plot within the same stratum.
To estimate total tree biomass from NFI data, allometric single-tree functions cited in Schmid et al. (2006) were used for stemwood, bark, twigs, branches and roots. To convert the volume of stemwood and branches to biomass, conversion factors for wood density were used as given in Assmann (1961). Biomass was converted to C assuming a carbon content of 50\% (IPCC 2003).

\section{Soil carbon model YASSO}

YASSO is an empirical and dynamic soil $\mathrm{C}$ model (Liski et al. 2005). It consists of two litter compartments describing the physical fractionation of litter, and five compartments describing microbial decomposition and humification processes in the soil. A detailed description of the model is given in Liski et al. (2005). As the model requires only basic information on litter quality (percentages of extractives, cellulose and lignin-like compounds) and climate such as mean annual temperature and summer drought (precipitation minus potential evapotranspiration between May and September), it can easily be linked to any calculation system that provides estimates of annual litter production. In MASSIMO, annual litter production was estimated by multiplying the different tree compartments by specific life spans plus the litter amount accumulating by natural mortality as given in Thürig et al. (2005b). The climatic dependency of the decomposition rates was determined from an analysis of litterbag data from across Europe and tested using data from Canada and Central America (Liski et al. 2003; Palosuo et al. 2005). The performance of YASSO with the Swiss NFI data was described and validated in Thürig et al. (2005b).

MASSIMO as well as YASSO was parameterized as described in Schmid et al. (2006). MASSIMO was initialized with NFI 2 data. YASSO was initialized by a spinup run with average annual litter-fall as assessed between 1985 and 1995 assuming a steady state. For more details, see Schmid et al. (2006).

\section{Windthrow}

Windthrow was implemented in the model as described in Thürig et al. (2005b). According to the observed damage of the largest three storm events (1967, 1990, 1999), three types of storm severities were distinguished and stochastically applied with an average but stochastic frequency of 15 years (Pfister 1999). The empirically defined storm area of $20000 \mathrm{~km}^{2}$ was randomly placed in the northern and central part of the country which are most affected by heavy storms (WSL and BUWAL 2001). Results of the model simulations were averaged out of 30 runs to account for the stochastic model parts. 


\section{Management scenarios}

Four different management scenarios focusing on different amounts of harvested wood and $\mathrm{C}$ sequestration were assessed in this study. In all four scenarios, a balanced age class distribution was reached in the even-aged forest within one rotation period by defining the annual forest area submitted to clear-cut accordingly.

In the basic scenario steady growing stock (SGS), rotation periods in the Plateau varied between 90 and 130 years and in the Alpine regions between 140 and 180 years, depending on the site quality. Frequencies as well as intensities of thinning were defined by empirical observations between the first and the second NFI, slightly modified to keep growing stock constant over a time period of at least 100 years. Every single tree had an individual probability to be removed when a stand was thinned, depending on the tree diameter, the development stage of the stand and the stand structure. These probabilities were also derived empirically from NFI data. Forest stands with very high harvesting costs as well as stands that were not managed for several decades were excluded from any management in the scenarios. Thus, about $6 \%$ of the productive forest area was established as forest reserves. This percentage is consistent with the current practice in Switzerland.

The other three scenarios were derived from the basic scenario SGS by mainly varying the rotation period and the frequency of thinning. For economical and silvicultural reasons, only the frequencies but not the intensities of thinning were varied. In the scenario reduced harvesting $(\mathrm{RH})$, rotation periods were extended by $50 \%$ compared to the basic scenario SGS. In the scenario increased harvesting (IH), rotation periods were shortened by $33 \%$ compared to SGS. In scenario RH, frequencies of thinning were divided by two compared to scenario SGS, and also the forest reserves were enhanced to $15 \%$ of the productive forest area in the Plateau and to $40 \%$ in the Alpine regions. In the scenario minimum forest management (MFM), forest management was reduced to decent thinning and gradual regenerations in the protection forest in mountainous regions.

\section{Results}

Figure 2 shows the development of $\mathrm{C}$ in living biomass and soil \& deadwood in the four specified management scenarios. For the whole of Switzerland, the scenarios suggest differences in the average annual carbon budget over the next 50 years (Table 1). Scenario SGS indicates a slightly increasing $\mathrm{C}$ stock of $0.3 \mathrm{t} \mathrm{C} \mathrm{ha}^{-1}$ year $^{-1}$ in biomass as well as $0.2 \mathrm{t} \mathrm{C} \mathrm{ha}^{-1}$ year $^{-1}$ in soil \& deadwood. In the next 20 years, the annual increase in biomass would be around 0.6 million $\mathrm{t} \mathrm{C}$ year $^{-1}$. Although the aim of the SGS scenario was to keep the level of the average growing stock per ha of Switzerland's forests constant, with this scenario the slight increase in growing stock would explain this sink effect (Table 2).

Scenario MFM would cause a strong increase of $2.1 \mathrm{t} \mathrm{C} \mathrm{ha}^{-1}$ year $^{-1}$ in biomass and $0.3 \mathrm{t} \mathrm{C} \mathrm{ha}^{-1}$ year $^{-1}$ in soil \& deadwood over the next 50 years. At the end of the century, however, the biomass under this scenario in the Swiss Eastern Plateau would become a C source, because with increasing stand density, the related mortality exceeds growth. This source would even be turned into a slight sink by soil \& deadwood that benefits from the mortality residues left on the forest floor. The scenario RH would bring about a total sink effect of $1.4 \mathrm{t} \mathrm{C} \mathrm{ha}^{-1}$ year $^{-1}$. Similar to scenario MFM, with scenario RH, the C stock would also become saturated after 2050. Over the next 50 years, scenario IH causes a source effect in biomass of $-0.4 \mathrm{t} \mathrm{C} \mathrm{ha}^{-1}$ year $^{-1}$. This source effect is diminished by a sink effect in soil \& deadwood (0.2 t C ha $^{-1}$ year $^{-1}$ ).

Regions, however, show quite different characteristics from Switzerland as a whole. In the Swiss Eastern Plateau, $\mathrm{C}$ budgets are generally much larger than the Swiss average, because growing conditions are above average. The changes in the biomass stock of scenario MFM indicate there would be a huge sink effect during the next 50 years of $3.9 \mathrm{t} \mathrm{C} \mathrm{ha}^{-1}$ year $^{-1}$, which would turn into a source in the second half of this century $\left(-0.4 \mathrm{t} \mathrm{C} \mathrm{ha}^{-1}\right.$ year $\left.^{-1}\right)$. Scenario RH indicates there would be a sink effect due to the total $\mathrm{C}$ stock changes for the next 50 years of $1.9 \mathrm{t} \mathrm{C} \mathrm{ha}^{-1}$ year $^{-1}$. Scenario $\mathrm{IH}$ forecasts a $\mathrm{C}$ source in the total $\mathrm{C}$ pool within the next 50 years of about $-1 \mathrm{t} \mathrm{C} \mathrm{ha}^{-1}$ year $^{-1}$. In the Swiss Eastern Alps, the $\mathrm{C}$ budgets simulated are much smaller than the Swiss average. It is striking that the carbon budgets simulated with the scenarios MFM and RH are similar. This is due to the fact that a large proportion of Alpine forests is also providing protection against rock-fall and avalanches. Therefore, the normal management practice is to keep forest interventions to a minimum to maintain the stability and functionality of protection forests.

The differences in the $\mathrm{C}$ budgets mean that the values for increment and cut \& mortality differ (Fig. 3). Based on the forest state in Switzerland of 1996, the results given in Fig. 3 and Table 2 for the entire Swiss forest have several implications. Increasing the amount of harvested timber during the next 20 years by more than $40 \%$ above the level of 1996 as in scenario $\mathrm{IH}$ would reduce growing stock and result in a reduction in the long-term increment and therefore also smaller amounts of timber that can be sustainably harvested in the long term. Increasing the amount 
Fig. 2 Simulated development of $\mathrm{C}$ stocks and stock changes in biomass and soil \& deadwood for the entire Swiss forest and separately for the regions Swiss Eastern Plateau and Swiss Eastern Alps. Simulations are made for the next 90 years assuming four different management scenarios; average C stocks per ha are presented
Switzerland
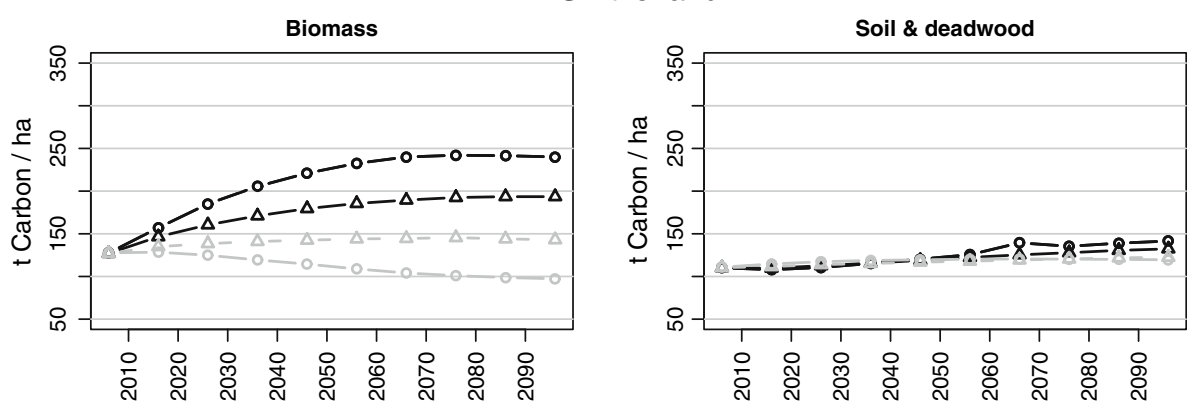

Swiss Eastern Plateau
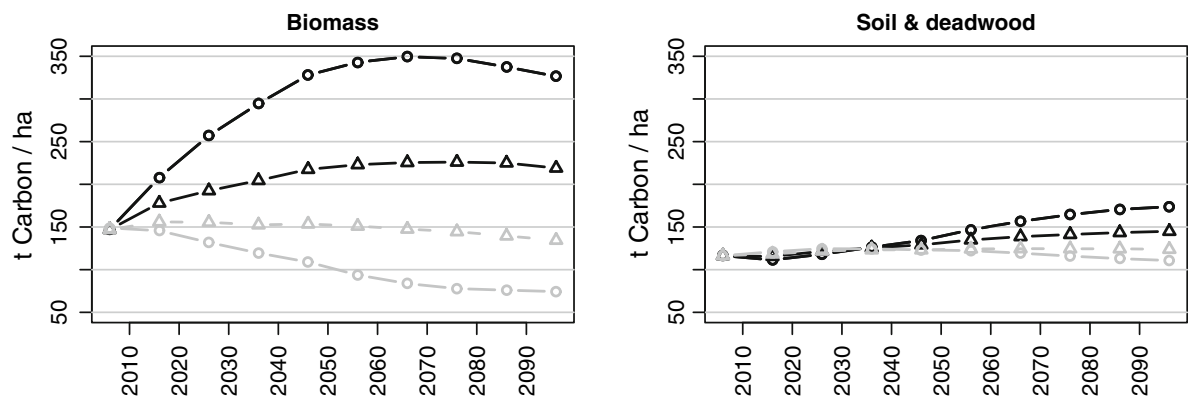

Swiss Eastern Alps
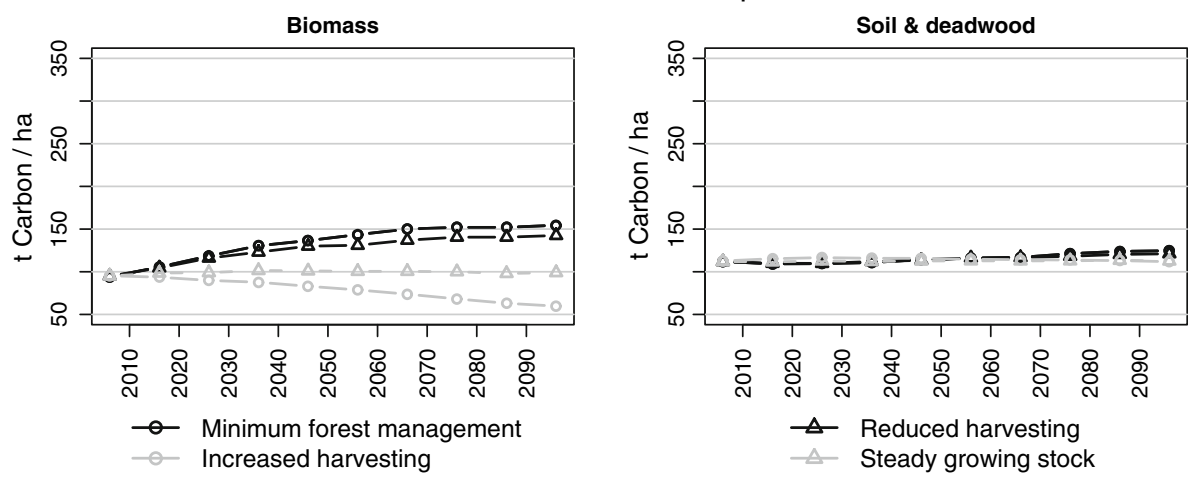

harvested by $18 \%$ above the level of 1996 as in scenario SGS, however, would result in a carbon sink accountable under the Kyoto Protocol. Scenario MFM would cause even smaller increments and increasing amounts of cut \& mortality.

As expected, the increment in the Swiss Eastern Plateau is much larger than the average for Switzerland as a whole because of the good site conditions. The losses by harvesting are large because of low-priced harvesting conditions (Fig. 3; Table 2). In scenario MFM, forests become a carbon source after 50 years due to constantly increasing mortality and a decreasing increment. In scenario $\mathrm{IH}$, the increment decreases quite drastically and reaches a level much below those in the scenarios SGS and RH. In the Swiss Eastern Alps, the increment is again much smaller than the Swiss average, because generally, growing conditions in the Swiss Eastern Alps are below the Swiss average. Losses by harvesting are low because of often high-priced harvesting conditions (Fig. 3; Table 2). Again, the scenarios MFM and RH are similar, because management practice is kept to a minimum to maintain the stability and functionality of protection forests. These simulation results indicate that the sink potential in such Alpine regions might be limited.

\section{Discussion}

The aim of this study was to assess the potential of forests in Switzerland as temporal carbon sink by increasing carbon stocks in the forest. In the following, the results of the four management scenarios are discussed in terms of their 
Table 1 Average annual $\mathrm{C}$ change in biomass and soil \& deadwood for different time periods

\begin{tabular}{|c|c|c|c|c|c|c|c|c|c|c|c|c|}
\hline \multirow[t]{2}{*}{ Period } & \multicolumn{3}{|c|}{ Steady growing stock (SGS) } & \multicolumn{3}{|c|}{ Minimum forest management (MFM) } & \multicolumn{3}{|c|}{ Reduced harvesting $(\mathrm{RH})$} & \multicolumn{3}{|c|}{ Increased harvesting $(\mathrm{IH})$} \\
\hline & Bio & Soil & Tot & Bio & Soil & Tot & Bio & Soil & Tot & Bio & Soil & Tot \\
\hline \multicolumn{13}{|l|}{ Switzerland } \\
\hline $2008-12$ & 0.80 & 0.13 & 0.93 & 2.95 & -0.22 & 2.73 & 1.95 & -0.05 & 1.90 & 0.08 & 0.37 & 0.45 \\
\hline $2007-26$ & 0.58 & 0.18 & 0.75 & 2.88 & 0.02 & 2.89 & 1.68 & 0.12 & 1.80 & -0.14 & 0.32 & 0.18 \\
\hline $2007-56$ & 0.34 & 0.15 & 0.49 & 2.10 & 0.31 & 2.41 & 1.17 & 0.24 & 1.41 & -0.38 & 0.19 & -0.19 \\
\hline 2057-96 & -0.03 & 0.12 & 0.09 & 0.19 & 0.40 & 0.59 & 0.20 & 0.25 & 0.45 & -0.29 & -0.02 & -0.31 \\
\hline \multicolumn{13}{|c|}{ Swiss Eastern Plateau } \\
\hline $2008-12$ & 0.90 & 0.20 & 1.10 & 6.10 & -0.50 & 5.60 & 3.10 & -0.08 & 3.02 & -0.33 & 0.47 & 0.14 \\
\hline $2007-26$ & 0.43 & 0.27 & 0.70 & 5.50 & 0.08 & 5.58 & 2.28 & 0.26 & 2.54 & -0.85 & 0.41 & -0.44 \\
\hline $2007-56$ & 0.08 & 0.16 & 0.24 & 3.92 & 0.61 & 4.53 & 1.52 & 0.37 & 1.89 & -1.10 & 0.12 & -0.98 \\
\hline 2057-96 & -0.41 & -0.01 & -0.42 & -0.41 & 0.67 & 0.26 & -0.10 & 0.25 & 0.15 & -0.48 & -0.29 & -0.77 \\
\hline \multicolumn{13}{|c|}{ Swiss Eastern Alps } \\
\hline $2008-12$ & 0.35 & -0.03 & 0.32 & 1.15 & -0.27 & 0.88 & 0.95 & -0.19 & 0.76 & -0.18 & 0.27 & 0.09 \\
\hline $2007-26$ & 0.20 & 0.04 & 0.24 & 1.23 & -0.12 & 1.10 & 1.05 & -0.10 & 0.95 & -0.28 & 0.20 & -0.08 \\
\hline $2007-56$ & 0.11 & 0.02 & 0.13 & 0.99 & 0.08 & 1.07 & 0.72 & 0.09 & 0.81 & -0.33 & 0.04 & -0.29 \\
\hline 2057-96 & -0.04 & -0.01 & -0.04 & 0.28 & 0.22 & 0.49 & 0.29 & 0.12 & 0.41 & -0.48 & -0.07 & -0.55 \\
\hline
\end{tabular}

Positive values indicate a carbon sink; negative values a carbon source

Bio annual $\mathrm{C}$ change in biomass in $\mathrm{t}_{\mathrm{Ch}}^{-1}$ year $^{-1}$, Soil annual $\mathrm{C}$ change in soil \& deadwood in $\mathrm{C}^{-1} \mathrm{year}^{-1}$, Tot total annual $\mathrm{C}$ change in t C ha ${ }^{-1}$ year $^{-1}$

Table 2 Values for growing stock $\left(\mathrm{m}^{3} \mathrm{ha}^{-1}\right)$ and average annual values of growth and cut \& mortality $\left(\mathrm{m}^{3} \mathrm{ha}^{-1}\right.$ year $\left.^{-1}\right)$ for different time periods

\begin{tabular}{|c|c|c|c|c|c|c|c|c|c|c|c|c|}
\hline \multirow[t]{2}{*}{ Period } & \multicolumn{3}{|c|}{ Steady growing stock (SGS) } & \multicolumn{3}{|c|}{ Minimum forest management (MFM) } & \multicolumn{3}{|c|}{ Reduced harvesting $(\mathrm{RH})$} & \multicolumn{3}{|c|}{ Increased harvesting $(\mathrm{IH})$} \\
\hline & GS & I & $\mathrm{CM}$ & GS & I & $\mathrm{CM}$ & GS & I & $\mathrm{CM}$ & GS & I & $\mathrm{CM}$ \\
\hline \multicolumn{13}{|c|}{ Switzerland } \\
\hline $1996^{\mathrm{a}}$ & 362 & 9.2 & 6.7 & 362 & 9.2 & 6.7 & 362 & 9.2 & 6.7 & 362 & 9.2 & 6.7 \\
\hline $2008-12$ & $364-372$ & 9.3 & 7.5 & $377-409$ & 10.3 & 2.4 & $371-391$ & 9.8 & 4.9 & $363-361$ & 9.1 & 9.4 \\
\hline $2007-26$ & $363-385$ & 9.1 & 7.9 & $370-516$ & 10.4 & 2.7 & $367-447$ & 9.8 & 5.5 & $363-346$ & 8.8 & 9.6 \\
\hline $2007-56$ & $363-395$ & 8.9 & 8.2 & $370-640$ & 9.9 & 4.3 & $367-510$ & 9.6 & 6.6 & $363-297$ & 8.4 & 9.7 \\
\hline $2057-96$ & $395-389$ & 8.7 & 8.8 & $642-638$ & 7.3 & 7.3 & $511-523$ & 8.7 & 8.4 & $295-260$ & 8.3 & 9.2 \\
\hline \multicolumn{13}{|c|}{ Swiss Eastern Plateau } \\
\hline $1996^{\mathrm{a}}$ & 422 & 13.4 & 11.9 & 422 & 13.4 & 11.9 & 422 & 13.4 & 11.9 & 422 & 13.4 & 11.9 \\
\hline $2008-12$ & $421-427$ & 15.4 & 13.7 & $449-512$ & 18.1 & 2.3 & $432-462$ & 16.6 & 9.0 & $419-412$ & 15.3 & 16.9 \\
\hline $2007-26$ & $420-428$ & 14.9 & 14.2 & $433-707$ & 18.2 & 3.7 & $424-528$ & 16.2 & 10.6 & $421-365$ & 14.5 & 17.1 \\
\hline $2007-56$ & $420-418$ & 14.5 & 14.4 & $433-922$ & 17.3 & 7.1 & $424-606$ & 16.3 & 12.4 & $421-264$ & 13.5 & 16.4 \\
\hline $2057-96$ & $417-379$ & 13.7 & 14.4 & $923-829$ & 11.6 & 13.8 & $607-595$ & 15.3 & 15.4 & $261-209$ & 11.2 & 12.5 \\
\hline \multicolumn{13}{|c|}{ Swiss Eastern Alps } \\
\hline $1996^{\mathrm{a}}$ & 304 & 6.0 & 4.6 & 304 & 6.0 & 4.6 & 304 & 6.0 & 4.6 & 304 & 6.0 & 4.6 \\
\hline $2008-12$ & $288-290$ & 4.9 & 4.3 & $290-302$ & 5.1 & 1.9 & $292-303$ & 5.3 & 2.5 & $286-283$ & 5.0 & 5.7 \\
\hline $2007-26$ & $287-293$ & 5.0 & 4.7 & $286-352$ & 5.4 & 2.0 & $289-346$ & 5.4 & 2.5 & $287-267$ & 4.9 & 6.0 \\
\hline $2007-56$ & $287-294$ & 4.8 & 4.7 & $286-424$ & 5.4 & 2.7 & $289-388$ & 5.3 & 3.3 & $287-226$ & 4.4 & 5.7 \\
\hline 2057-96 & $293-280$ & 4.4 & 4.7 & $425-447$ & 4.6 & 4.1 & $390-415$ & 4.6 & 4.0 & $225-164$ & 3.9 & 5.5 \\
\hline
\end{tabular}

Values are all given in stemwood including bark, stump and tree top. $G S$ growing stock at the beginning and at the end of the period in $\mathrm{m}^{3}$ ha ${ }^{-1}$, $I$ annual increment in $\mathrm{m}^{3} \mathrm{ha}^{-1}$ year $^{-1}, C M$ annual amount of cut $\&$ mortality in $\mathrm{m}^{3} \mathrm{ha}^{-1}$ year $^{-1}$

a According to Brassel et al. (1999) 

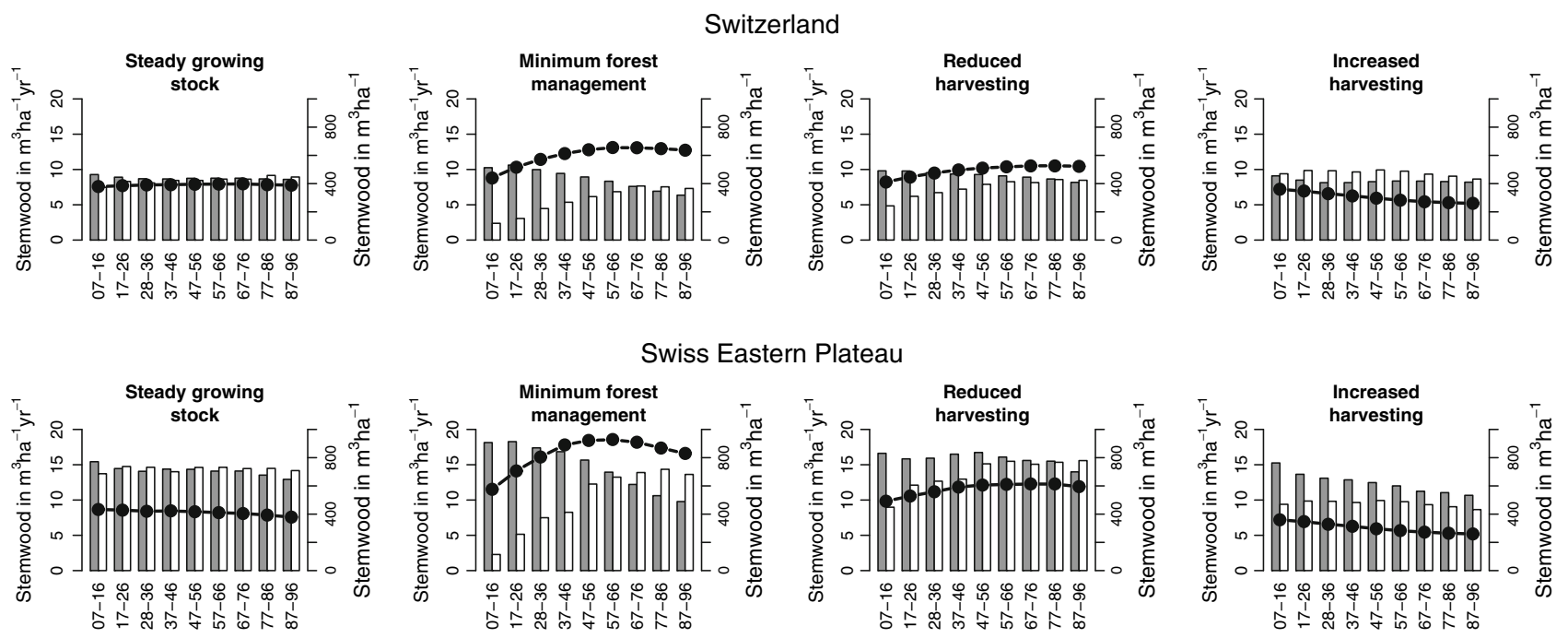

Swiss Eastern Alps

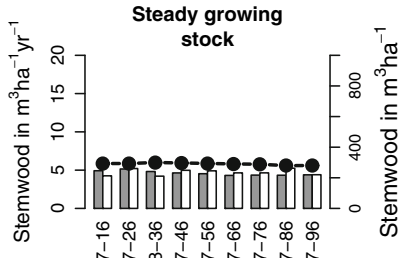

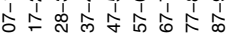

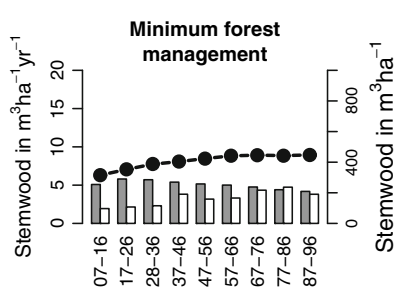

$\square$ Increment (left axis)
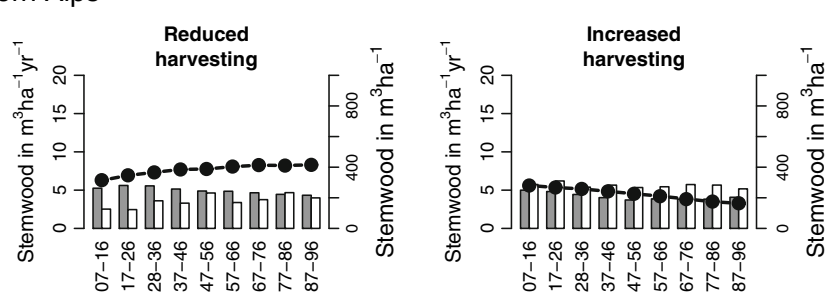

$\square$ Cut \& Mortality (left axis)

Fig. 3 Scenarios of growing stock in $\mathrm{m}^{3} \mathrm{ha}^{-1}$ and increment and cut \& mortality for the next 90 years in stemwood (including bark, stump and tree top) in $\mathrm{m}^{3} \mathrm{ha}^{-1}$ year ${ }^{-1}$. Increment and cut $\&$ mortality are displayed on the left $y$-axis and growing stock on the right $y$-axis

effectiveness on mitigating the increase in atmospheric carbon dioxide.

Increasing forest $\mathrm{C}$ sink through minimum forest management (MFM) or reduced harvesting (RH)?

Our results indicate that the potential of forests as carbon sink can be maximized for a short time by minimizing forest management and thus maximizing the sink effect of forests or a smaller sink can be created by simply reducing the harvesting amount. However, MFM and RH are no stable and sustainable scenarios due to following restrictions. The results take into account the frequency of heavy windstorms as observed during the last 40 years and the damage they caused (Thürig et al. 2005b). The maximum stand density was also limited as described in Schmid et al. (2006). Secondary damage, for example, caused by bark beetles, however, has not yet been taken into account. Moreover, the globally important effect of forest fire on the carbon balance (Mouillot et al. 2006) was also not considered in our simulations, because so far, only small areas have been affected in Switzerland. Due to an increase in climate variability (Schär et al. 2004), increase in climatic extremes such as heavy windstorms and secondary damage such as forest fires and bark-beetle infestations are to be expected. An Austrian study of secondary Norway spruce stands indicated an increase in bark beetle damage up to $+219 \%$ in terms of timber volume losses under climate change scenarios (Seidl et al. 2008). Additionally, by reducing the harvesting amount, less timber is available to replace more $\mathrm{CO}_{2}$ intensive construction material such as concrete or steel, which also increases $\mathrm{CO}_{2}$ emissions (Taylor et al. 2008).

In the Swiss Eastern Plateau with minimum forest management, the potential for forests to act as carbon sink over the next 50 years is considerable (Table 1). However, given the above-mentioned restrictions and risks, and the currently high prices for timber, this scenario seems ecologically and economically less attractive for most of the forest areas in the Swiss Eastern Plateau. In the Swiss Eastern Alps, harvesting costs are generally higher than in the Swiss Eastern Plateau, and therefore, for forests to act as a carbon sink seems to be a new economically attractive function. However, the results of this study suggest that this potential sink seems to be small, because the productivity is lower than the Swiss average. Moreover, much of the Alpine forest area has to fulfil a protection function, so 
that most of the forest area is commonly subject to forest management to maintain the protection function. Therefore, it can be concluded that, although the MFM scenario leads to the highest carbon sequestration, the potential sink is still small.

Decreasing forest $\mathrm{C}$ stocks by increased harvesting (IH)?

Our study indicates that, for the next 20 years, the increased harvesting scenario lowers the growing stock by $16 \mathrm{~m}^{3}$ stemwood per ha and generates an average annual carbon loss in the biomass of $0.14 \mathrm{t} \mathrm{C}$ per ha or 0.15 million $\mathrm{t}$ C. Although this scenario has this source effect in forests, it also helps reduce $\mathrm{CO}_{2}$ emissions by increasing the substitution effect of wood when replacing fossil fuel and energy-intensively produced construction material such as cement or steel. If less timber and wood fibre were available to meet such social needs, the use of energyintensive materials such as concrete or steel and fossil fuel would increase resulting in higher greenhouse gas emissions (Gustavsson and Sathre 2006). Therefore, to assess of the overall impact of forests on mitigating climate change, the substitution effect of harvested wood products (HWPs) has to be taken into account, for example, as in Taverna et al. (2007) and Werner et al. (2010).

The increased harvesting scenario may lead to a reduction in growth. In the Swiss Eastern Plateau, for example, where the increase in harvesting amount and the consequential decrease in growing stock are especially large, the increment, i.e. the actual production of timber as a resource, will decrease in the long term. We, therefore, conclude that, if harvesting is increased, the growing stock and increment should be regionally monitored to avoid overexploitation of forests.

Maximizing the long-term harvesting amount and sustainable, high increment

The results of our study indicate that, with the scenario steady growing stock, three goals towards mitigating climate change can be combined. First, a sustainable high increment can be created by increasing the amount harvested by $18 \%$ above the 1996 level. Second, this larger volume of HWPs can then be used to substitute more energy-intensive products as well as fossil fuels. Third, increasing the forest carbon stocks brings about a sink effect of around 0.6 million t C per year, which is slightly more than the Swiss amount accountable under the Kyoto Protocol ( 0.5 million t $\mathrm{C}$ per year). These findings are in line with those in the Intergovernmental Panel on Climate Change (IPCC) Fourth Assessment Report (Nabuurs et al. 2007, p. 543), where such forest management strategies generate the largest sustained climate change mitigation benefit.

In this article, the $\mathrm{CO}_{2}$ effects of using more HWP and the substitution effects of replacing non-wood products and fossil fuels are not considered. Hennigar et al. (2008) suggest that, by focusing only on forest systems, spurious C maximization in forests can happen. However, with the suggested forest management strategy that aims to promote a sustainable and harvestable increment, such unilateral incentives can be avoided. Taverna et al. (2007) and Werner et al. (2010) investigated the combined $\mathrm{CO}_{2}$ effect of forests and wood industries by combining the forest management scenarios of this study with different wood use scenarios. By simulating wood flows, wood stocks and substitution effects, they came up with following climatepolicy-optimized recommendations: First, the maximum possible increment that is also sustainable should be generated in the forest. Second, this increment should be exploited through wood harvesting. Third, the harvested wood should be processed in accordance with the principle of cascade use. Fourth, waste wood that is not suitable for further use should be used to generate energy.

Eriksson and Berg (2007) found that, for some forest stands, a very short rotation period of 60 years was preferable to mitigate net $\mathrm{CO}_{2}$ emissions. This differs from our results possibly because of the differences in the initial situation, the growth conditions, and the fact that Eriksson and Berg (2007) is a case study. The discrepancy in the findings indicates that there is not one solution for all spatial scales, regions and forest types, but an optimum has to be found for different initial situations, forest functions and other requirements (Millar et al. 2007; Nabuurs et al. 2008).

The optimal timing for the use of forests as carbon sinks mainly depends on how long forest growth can be maintained at a high level (Kirschbaum 2003). Our study suggests that the already large growing stocks in Switzerland still show large increments. This is in line with the findings of Luyssaert et al. (2008) who reviewed the literature and databases for forest carbon-flux estimates and found that forests up to a stand age of 800 years might display positive net ecosystem productivities and therefore serve as $\mathrm{C}$ sinks. However, as mentioned above, the increase in climatic extremes could necessitate a regional reduction in growing stock to ensure forest stability.

In our study, the Swiss forest area was kept constant at the level of 1.065 million hectares. As stated in the Switzerland's Initial Report under Article 7, paragraph 4 of the Kyoto Protocol (FOEN 2006), for deforestation, an official permission is necessary, and compensating measures (mostly afforestations) are mandatory. Annual losses due to deforestation are, therefore, small. In fact, the forest area in Switzerland is increasing due to the abandonment of 
grazing land (Rutherford et al. 2008). Although Eggers et al. (2008) showed that sink effects due to relatively small-scale afforestations are small, this aspect of land-use change should be taken into account in further studies, especially in the Alps (Zierl and Bugmann 2007).

Storm damage observed over the past 40 years was taken into account in this study (Thürig et al. 2005b), but other changes in environmental conditions, such as increased temperature, number of climatic extreme events, risk of insect damages (Kurz et al. 2008), or changed levels of precipitation were not considered. Zaehle et al. (2007) found that the differences in the IPCC climate change scenarios were the main reason for the uncertainty in the simulations of the European terrestrial $\mathrm{C}$ uptake of 4.410.1 Pg C between 1990 and 2100. Eggers et al. (2008) simulated the development of forest resources in the twenty-first century under four different IPCC climate scenarios for 15 European countries. According to their simulations, climate change will lead to increased forest growth of $0.4-0.5 \mathrm{~m}^{3} \mathrm{ha}^{-1}$ per year in 2030 and $0.6-$ $0.7 \mathrm{~m}^{3} \mathrm{ha}^{-1}$ per year in 2050. Contrarily, Ciais et al. (2005) show that with an increase in extreme summer drought, growth will probably be strongly reduced, and Piao et al. (2008) suggest that northern terrestrial ecosystems may be currently losing carbon dioxide in response to autumn warming by about $0.2 \mathrm{Pg} \mathrm{C}$ per degree Celsius. Similar results were obtained by Zierl and Bugmann (2007). They assume that the warming trend described in the IPCC Special Report on Emissions Scenarios will only enhance carbon sequestration during the first half of the twenty-first century. Thereafter, forests at low elevations will increasingly release carbon as a consequence of the changed balance between growth and respiration processes. All these studies show that further research on long-term scenarios of forest development should concentrate on modelling not only temperature anomalies and trends, but also precipitation. In particular, they should investigate the combined effects of these factors on forest growth, mortality and regeneration.

\section{Conclusions}

Models of forest development with differing management scenarios and carbon budgets may support management decisions where the forest has to fulfil conflicting requirements. From our simulation study, we can conclude: (1) A forest management strategy aiming for a sustainable and harvestable increment may enhance the contribution of forests to mitigate climate change and avoid spurious $\mathrm{C}$ maximization in forests. The latter can happen if only forest systems are considered, but not products and substitution effects. (2) Alpine forests in Switzerland may have limited effects as carbon sinks, because first, common management practice involves a minimal intervention in forests with a protection function; and second, growth in these regions is often low. (3) A large increase in amounts harvested would cause a (regional) $\mathrm{C}$ source. This would mean monitoring on regional scales to avoid overexploitation and a decrease in increment.

Acknowledgment This study was funded by the Swiss Federal Office for the Environment FOEN. We thank Silvia Dingwall for the language revision. We also thank two anonymous reviewers for constructive comments on an earlier version of this paper.

\section{References}

Assmann E (1961) Waldertragskunde-Organische Produktion. Struktur, Zuwachs und Ertrag von Waldbeständen. BLV Vertragsgesellschaft München Bonn Wien, p 79

Birdsey R, Pregitzer K, Lucier A (2006) Forest carbon management in the United States: 1600-2100. J Environ Qual 35(4):1461-1469

Brassel P, Brändli U-B (eds) (1999) Schweizerisches Landesforstinventar: Ergebnisse der Zweitaufnahme 1993-1995. Eidgenössische Forschungsanstalt für Wald, Schnee und Landschaft (WSL). Bern, Haupt

Ciais P, Reichstein M, Viovy N, Granier A, Ogee J, Allard V, Aubinet M, Buchmann N, Bernhofer C, Carrara A, Chevallier F, De Noblet N, Friend AD, Friedlingstein P, Grünwald T, Heinesch B, Keronen P, Knohl A, Krinner G, Loustau D, Manca G, Matteucci G, Miglietta F, Ourcival JM, Papale D, Pilegaard K, Rambal S, Seufert G, Soussana JF, Sanz MJ, Schulze ED, Vesala T, Valentini R (2005) Europewide reduction in primary productivity caused by the heat and drought in 2003. Nature 437:529-533

Ciais P, Schelhaas MJ, Zaehle S, Piao SL, Cescatti A, Liski J, Luyssaert S, Le-Maire G, Schulze ED, Bouriaud O, Freibauer A, Valentini R, Nabuurs GJ (2008) Carbon accumulation in European forests. Nat Geosci 1(7):425-429

De Vries W, Reinds GJ, Gundersen P, Sterba H (2006) The impact of nitrogen deposition on carbon sequestration in European forests and forest soils. Glob Chang Biol 12(7):1151-1173

Eggers J, Lindner M, Zudin S, Zaehle S, Liski J (2008) Impact of changing wood demand, climate and land use on European forest resources and carbon stocks during the 21 st century. Glob Chang Biol 14(10):2288-2303

Eriksson E, Berg S (2007) Implications of environmental quality objectives on the potential of forestry to reduce net $\mathrm{CO}_{2}$ emissionsa case study in central Sweden. Forestry 80(2):99-111

FOEN (2006) Switzerland's initial report under Article 7, paragraph 4 of the Kyoto Protocol

Goodale CL, Apps MJ, Birdsey RA, Field CB, Heath LS, Houghton RA, Jenkins JC, Kohlmaier GH, Kurz W, Liu SR, Nabuurs GJ, Nilsson S, Shvidenko AZ (2002) Forest carbon sinks in the Northern hemisphere. Ecol Appl 12(3):891-899

Gustavsson L, Sathre R (2006) Variability in energy and carbon dioxide balances of wood and concrete building materials. Build Environ 41(7):940-951

Harmon ME (2001) Carbon sequestration in forests-addressing the scale question. J For 99(4):24-29

Hennigar CR, MacLean DA, Amos-Binks LJ (2008) A novel approach to optimize management strategies for carbon stored in both forests and wood products. For Ecol Manag 256(4):786-797

IPCC (2003) Good practice guidance for land use, land-use change and forestry, intergovernmental panel on climate change. Institute for Global Environmental Strategies, Hayama, Japan 
Karjalainen T, Pussinen A, Liski J, Nabuurs G-J, Eggers T, Lapveteläinen T, Kaipainen T (2003) Scenario analysis of the impacts of forest management and climate change on the European forest sector carbon budget. For Policy Econ 5(2):141-155

Kaufmann E (2000a) Estimation of standing timber, growth and cut. In: Brassel P, Lischke $\mathrm{H}$ (eds) Swiss national forest inventory: methods and models of the second assessment. Swiss Federal Research Institute WSL, Birmensdorf, pp 162-196

Kaufmann E (2000b) Prognosis and management scenarios. In: Brassel P, Lischke $\mathrm{H}$ (eds) Swiss national forest inventory: methods and models of the second assessment. Swiss Federal Research Institute WSL, Birmensdorf, pp 197-206

Kirschbaum MUF (2003) To sink or burn? A discussion of the potential contributions of forests to greenhouse gas balances through storing carbon or providing biofuels. Biomass Bioenergy 24(4-5):297-310

Kurz WA, Stinson G, Rampley GJ, Dymond CC, Neilson ET (2008) Risk of natural disturbances makes future contribution of Canada's forests to the global carbon cycle highly uncertain. Proc Natl Acad Sci USA 105(5):1551-1555

Liski J, Nissinen A, Erhard M, Taskinen O (2003) Climatic effects on litter decomposition from arctic tundra to tropical rainforest. Glob Chang Biol 9:575-584

Liski J, Palosuo T, Peltoniemi M, Sievänen R (2005) Carbon and decomposition model Yasso for forest soils. Ecol Modell 189:168-182

Liski J, Lehtonen A, Palosuo T, Peltoniemi M, Eggers T, Muukkonen P, Makipaa R (2006) Carbon accumulation in Finland's forests 1922-2004 - an estimate obtained by combination of forest inventory data with modelling of biomass, litter and soil. Ann For Sci 63(7):687-697

Luyssaert S, Schulze ED, Borner A, Knohl A, Hessenmoller D, Law BE, Ciais P, Grace J (2008) Old-growth forests as global carbon sinks. Nature 455(7210):213-215

Magnani F, Mencuccini M, Borghetti M, Berbigier P, Berninger F, Delzon S, Grelle A, Hari P, Jarvis PG, Kolari P, Kowalski AS, Lankreijer H, Law BE, Lindroth A, Loustau D, Manca G, Moncrieff JB, Rayment M, Tedeschi V, Valentini R, Grace J (2007) The human footprint in the carbon cycle of temperate and boreal forests. Nature 447(7146):849-851

Millar CI, Stephenson NL, Stephens SL (2007) Climate change and forests of the future: managing in the face of uncertainty. Ecol Appl 17(8):2145-2151

Mouillot F, Narasimha A, Balkanski Y, Lamarque J-F, Field CB (2006) Global carbon emissions from biomass burning in the 20th century. Geophys Res Lett 33:L01801. doi:10.1029/2005GL024707

Nabuurs GJ, Masera O, Andrasko K, Benitez-Ponce P, Boer R, Dutschke M, Elsiddig E, Ford-Robertson J, Frumhoff $P$, Karjalainen T, Krankina O, Kurz WA, Matsumoto M, Oyhantcabal W, Ravindranath NH, Sanz Sanchez MJ, Zhang X (2007) Forestry. In: Metz B, Davidson OR, Bosch PR, Dave R, Meyer LA (eds) Climate change 2007: mitigation. Contribution of working group III to the fourth assessment report of the intergovernmental panel on climate change. Cambridge University Press, Cambridge, New York

Nabuurs GJ, Thürig E, Heidema N, Armolaitis K, Biber P, Cienciala E, Kaufmann E, Mäkipää R, Nilsen P, Petritsch R, Pristova T, Rock J, Schelhaas MJ, Sievanen R, Somogyi Z, Vallet P (2008) Hotspots of the European forests carbon cycle. For Ecol Manag 256(3):194-200

Pacala SW, Hurtt GC, Baker D, Peylin P, Houghton RA, Birdsey R, Heath L, Sundquist ET, Stallard RF, Ciais P, Moorcroft P, Caspersen JP, Shevliakova E, Moore B, Kohlmaier GH, Holland EA, Gloor M, Harmon ME, Fan SM, Sarmiento J, Goodale CL,
Schimel DS, Field CB (2001) Consistent land- and atmospherebased U.S. carbon sink estimates. Science 292:2316-2320

Palosuo T, Liski J, Trofymow JA, Titus BD (2005) Litter decomposition affected by climate and litter quality-testing the Yasso model with litterbag data from the Canadian intersite decomposition experiment. Ecol Modell 189:183-198

Pfister C (1999) Wetternachhersage. 500 Jahre Klimavariationen und Naturkatastrophen (1496-1995). Bern, Verlag P. Haupt

Piao S, Ciais P, Friedlingstein P, Peylin P, Reichstein M, Luyssaert S, Margolis H, Fang J, Barr A, Chen A, Grelle A, Hollinger DY, Laurila T, Lindroth A, Richardson AD, Vesala T (2008) Net carbon dioxide losses of northern ecosystems in response to autumn warming. Nature 451(7174):49-52

Rutherford GN, Bebi P, Edwards PJ, Zimmermann NE (2008) Assessing land-use statistics to model land cover change in a mountainous landscape in the European Alps. Ecol Modell 212(3-4):460-471

Schär C, Vidale PL, Lüthi D, Frei C, Häberli C, Liniger M, Appenzeller C (2004) The role of increasing temperature variability in European summer heat waves. Nature 427:332-336

Schlamadinger B, Marland G (1996) The role of forest and bioenergy strategies in the global carbon cycle. Biomass Bioenergy 10(5-6): 275-300

Schmid S, Thürig E, Kaufmann E, Lischke H, Bugmann H (2006) Effect of forest management on future carbon pools and fluxes: a model comparison. For Ecol Manag 237(1-3):65-82

Seidl R, Rammer W, Jäger D, Lexer MJ (2008) Impact of bark beetle (Ips typographus L.) disturbance on timber production and carbon sequestration in different management strategies under climate change. For Ecol Manag 256(3):209-220

Taverna R, Hofer P, Werner F, Kaufmann E, Thürig E (2007). The $\mathrm{CO}_{2}$ effects of the Swiss forestry and timber industry. Scenarios of future potential for climate-change mitigation. Environmental studies no. 0739, Federal Office for the Environment

Taylor AR, Wang JR, Kurz WA (2008) Effects of harvesting intensity on carbon stocks in eastern Canadian red spruce (Picea rubens) forests: An exploratory analysis using the CBM-CFS3 simulation model. For Ecol Manag 255(10):3632-3641

Thürig E, Kaufmann E, Frisullo R, Bugmann H (2005a) Evaluation of the growth function of an empirical forest scenario model. For Ecol Manag 204(1):53-68

Thürig E, Palosuo T, Bucher J, Kaufmann E (2005b) The impact of windthrow on carbon sequestration in Switzerland: a modelbased assessment. For Ecol Manag 210:337-350

UNFCCC (1997) Kyoto Protocol to the United Nations framework convention on climate change. Document FCCC/CP/1997/7/Add.1

Watson RT, Noble IR, Bolin B, Ravindranath NH, Verardo DJ, Dokken DJ (eds) (2000) Land use, land-use change, and forestry, Intergovernmental Panel on Climate Change. Cambridge University Press, Cambridge

Werner F, Taverna R, Hofer P, Thürig E, Kaufmann E (2010) National and global greenhouse gas dynamics of different forest management and wood use scenarios: a model-based assessment. Environ Sci Policy 13:72-85

WSL, BUWAL (eds) (2001) Lothar. Der Orkan 1999. Ereignisanalyse. Birmensdorf, Bern, Eidgenössische Forschungsanstalt WSL, Bundesamt für Umwelt, Wald und Landschaft BUWAL

Zaehle S, Bondeau A, Carter TR, Cramer W, Erhard M, Prentice IC, Reginster I, Rounsevell MDA, Sitch S, Smith B, Smith PC, Sykes M (2007) Projected changes in terrestrial carbon storage in Europe under climate and land-use change, 1990-2100. Ecosystems 10(3):380-401

Zierl B, Bugmann H (2007) Sensitivity of carbon cycling in the European Alps to changes of climate and land cover. Clim Change 85(1-2):195-212 